\title{
Effect of Coal Gases on Electrochemical Reactions in the Direct Carbon Fuel Cell System
}

\author{
Seongyong Eom, Seongyool Ahn, Younghoon Rhie, Gyungmin Choi, and Duckjool Kim
}

\begin{abstract}
Various carbonaceous fuels were evaluated in a Direct Carbon Fuel Cell (DCFC) system as energy sources. In order to investigate the characteristics of electrochemical reaction of various fuels in DCFC, three coals, such as Shenhua coal, Adaro coal, and Openblue coal which have different content of fixed carbon and volatile matter, were selected in this research. The characteristics of electrochemical reactions of fuels were investigated at $700^{\circ} \mathrm{C}$ by potentiostatic method of the fuel cell and the effect of fuels properties is also discussed. The effect of gases from coals was investigated by using raw coal state and char state in present work. The gases, such as $\mathrm{H}_{2}, \mathrm{CH}_{4}$, $\mathrm{CO}$ and $\mathrm{CO}_{2}$, were detected in the exhaust gas of anode side by thermal decomposition of coal. It is confirmed that these gases have an effect on the electrochemical reaction on DCFC system by comparing of current density of raw coal and char.
\end{abstract}

Index Terms-Direct carbon fuel cell, coal, fuel gasification, volatile matter.

\section{INTRODUCTION}

According as the amount of fossil fuel increases, the exhaustion of resources and the environmental pollution have emerged as a serious problem in the world. Many researchers make a lot of effort such as increasing efficiency and developing technique of reducing pollution in existing coal thermal power generation, but these solutions are limited. The fuel cell, one of the alternative power generations, has come into the spotlight due to high efficiency and eco-friendly. The high temperature fuel cell which has the advantage of not using metal catalysts and high efficiency has been focused as a technology to replace the existing thermal power generation, especially [1].

The Direct Carbon Fuel Cell (DCFC), one of the high temperature fuel cell, has been investigated by many research groups. The DCFC that uses solid carbon directly has been investigated by many research groups because of dramatically high efficiency. The performances of this fuel cell depend on the characteristics of electrochemical oxidation reaction of

Manuscript received November 24, 2013; revised January 22, 2014. This work was supported by the National Research Foundation of Korea (NRF) grant funded by the Korea government (MEST) (No. 2011-0027954) and the Human Resources Development program(No. 20124010203230) of the Korea Institute of Energy Technology Evaluation and Planning(KETEP) grant funded by the Korea government Ministry of Knowledge Economy.

S. Y. Eom and Y. H. Rhie are with the Graduation School of Mechanica Engineering, Pusan National University, Korea (e-mail: eom912@ pusan.ac.kr,yiyh@ pusan.ac.kr).

S. Y. Ahn was with Pusan National University, Korea. He is now with the CRIEPI, Japan (e-mail: syahn405@gmail.com).

G. M. Choi and D. J. Kim are with the School of Mechanical Engineering, Pusan National University, Korea (e-mail: choigm@ pusan.ac.kr, djkim@ pusan.ac.kr). carbonaceous fuel as anode. The DCFC has a definite advantage of fuel flexibility such as coal, biomass, wastes, etc. [1]-[4].

Many research groups have studied the DCFC based on the molten carbonate fuel cell to produce electricity in the fuel. Vutetakis et al. [5] studied the electrochemical reactions according the coal types and the operating conditions. Li et al. [6]-[8] investigated the impact of fuels characteristics on the DCFC performance.

This work focuses on the correlation fuels characteristics and electrochemical reactions in the DCFC system. To investigate the effect of various fuel properties in DCFC, three different rank coals and chars (Shenhua coal, Adaro coal, and Openblue coal) were selected in this research. The chars were carbonized to remove volatile matter. The potential and the power density of each fuel were measured for performance comparison in DCFC system. The characteristics of fuels such as thermal reactivity, specific surface area, pore volume, and functional groups on the fuel surface were analyzed through four analysis method; TGA (thermogravimetric analysis), BET (Brunauer-Emmett-Teller test), and XPS (X-ray photoelectron spectroscopy). Moreover, the influence of gases generated in fuel pyrolysis was investigated by using raw coal state and char state. The correlation of these properties and electrochemical reactions was discussed by means of $i$-V, $i$-p and EIS.

\section{EXPERIMENT}

\section{A. Preparation of Sample and Analysis of Coal Characteristics}

To compare fuel characteristic and electrochemical oxidation reaction, three coals (Shenhua coal in bituminous, Adaro coal and Openblue coal in sub-bituminous) were selected as different carbon content fuel. All fuels were sieved to $2 \sim 3 \mathrm{~mm}$ particle sizes. The moisture out of all samples was driven at $110^{\circ} \mathrm{C}$ for $30 \mathrm{~min}$. TCOhe raw coal samples were carbonized from room temperature to $700^{\circ} \mathrm{C}$ as $10{ }^{\circ} \mathrm{C} / \mathrm{min}$ of heating rate under Argon gas. After carbonization, the furnace was cooled to room temperature in Argon gas.

The carbonaceous solid fuels were used in the DCFC based molten carbonates. This fact results in importance of the fuel analysis because the solid fuel was used instead of $\mathrm{H}_{2}$ gas in other fuel cells. Therefore, the fuel analysis was performed to investigate the relation between fuel properties and the oxidation reactions [9], [10]. All fuel samples were conducted by proximate analysis and ultimate analysis and shown in Table I. The proximate analysis was conducted by TGA (SDT-Q600, TA instrument) using a standard American 
Society for Testing and Materials (ASTM). Significant fuel properties, such as the thermal reaction, the crystallinity, the specific surface area and the surface functional groups, were analyzed by various methods of Thermo-gravimetric Analysis (TGA), Gas adsorption (BET), X-ray Photoelectron Spectroscopy (XPS).

TABLE I: PROXIMATE AND Ultimate ANALYSIS OF COALS ACCORDING TO ASTM STANDARDS

\begin{tabular}{|c|c|c|c|c|c|c|c|c|}
\hline \multirow{2}{*}{ Sample } & \multicolumn{3}{|c|}{ Proximate analysis $^{\text {a }}(\mathrm{wt.} \%)$} & \multicolumn{5}{|c|}{ Ultimate analysis ${ }^{b}$ (wt.\%) } \\
\hline & VM & FC & Ash & $\mathbf{C}$ & $\mathbf{H}$ & $\mathbf{O}$ & $\mathbf{N}$ & $\mathbf{S}$ \\
\hline Shenhua coal & 32.29 & 58.67 & 9.04 & 75.90 & 4.81 & 10.15 & 1.40 & - \\
\hline Adaro coal & 47.99 & 50.20 & 1.80 & 71.20 & 5.27 & 18.93 & 1.28 & 0.03 \\
\hline Openblue coal & 52.37 & 44.84 & 2.78 & 53.4 & 4.78 & 26.92 & 0.62 & 0.23 \\
\hline Shenhua char & 6.94 & 79.86 & 13.20 & 84.19 & 1.06 & 0.06 & 1.82 & 0.27 \\
\hline Adaro char & 8.89 & 78.75 & 12.36 & 82.53 & 1.01 & 0.87 & 1.91 & 0.25 \\
\hline Openblue char & 10.18 & 83.17 & 6.65 & 88.74 & 0.87 & 0.53 & 1.70 & 0.31 \\
\hline a, b dry basis & & & & & & & & \\
\hline
\end{tabular}

\section{B. DCFC Experimental System}

In this paper, the experiment was consisted of half-cell part and performance evaluation part of DCFC system [9], [10]. Fig. 1 shows a schematic diagram of half-cell of DCFC. The electrolyte was dried at $110^{\circ} \mathrm{C}$ for $30 \mathrm{~min}$ and mixed with 62:38 ratios of $\mathrm{Li}_{2} \mathrm{CO}_{3}$ and $\mathrm{K}_{2} \mathrm{CO}_{3}$. In each experiment, the fuel and electrolyte were used in $46 \mathrm{~g}$ and $460 \mathrm{~g}$, respectively. Three electrodes made from silver were used as the working electrode, the counter electrode, and the reference electrode, respectively. The current density and power density were calculated on considering the effective area of working electrode $\left(1.34 \mathrm{~cm}^{2}\right.$ in the standard cell). The counter electrode and the reference electrode were separated from fuels by the alumina tube. Before reaching the operating temperature, the part of the working electrode was injected with $\operatorname{Ar}(150 \mathrm{ml} / \mathrm{min})$ and the counter electrode and the reference electrode were filled with $\mathrm{CO}_{2}(50 \mathrm{ml} / \mathrm{min})$. After that, a mixed gas of $\mathrm{O}_{2}(25 \mathrm{ml} / \mathrm{min})$ and $\mathrm{CO}_{2}(50 \mathrm{ml} / \mathrm{min})$ was fed into the counter electrode and the reference electrode at keeping stable OCV.

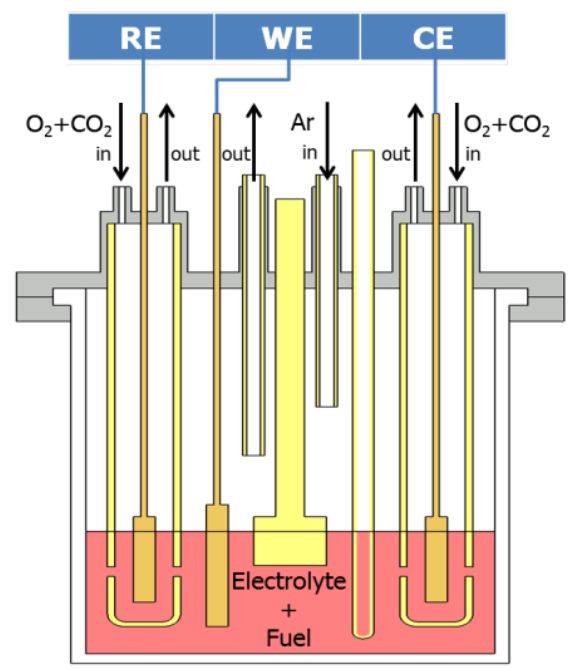

Fig. 1. Schematic diagram of the experimental system.

\section{RESULTS AND DISCUSSION}

\section{A. Fuel Properties}

Fig. 2 shows TG results with respect to raw coal and char state under Ar conditions. This figure represents reaction of solid fuel with increasing temperature. In the case of char state, weight of three char was decreased between $600^{\circ} \mathrm{C}$ and $700^{\circ} \mathrm{C}$.
The weight loss by thermo-decomposition is within $5 \%$. Judging from this result, the carbon of char fuels almost remain solid phase. On the contrary, the raw coals show the weight change from $300{ }^{\circ} \mathrm{C}$. The volatile matter of coal eliminated through thermal decomposition process. After reaching $700^{\circ} \mathrm{C}$, weight variation of coals change $1-2 \%$ during 1 hour. This is similar to the char TG results. Based on these results, to correlate fuel properties and electrochemical reaction at operating temperature, char properties should be used for accurate analysis instead of raw coal.

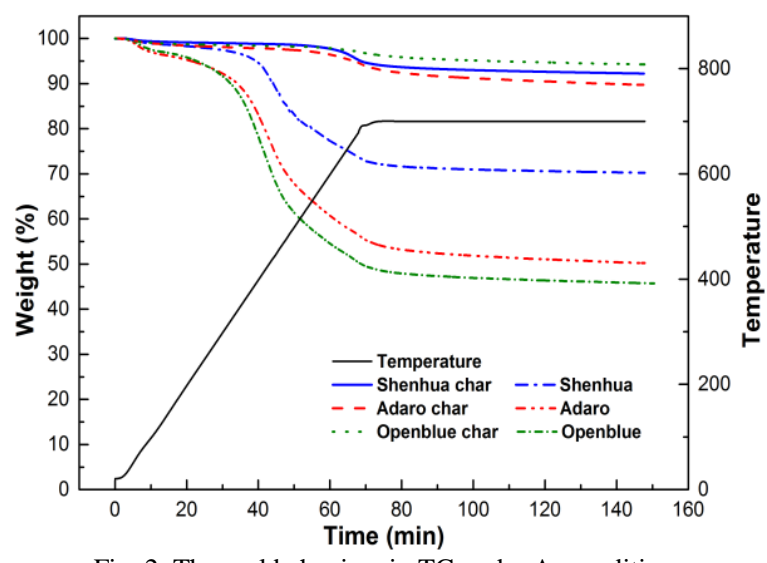

Fig. 2. Thermal behaviors in TG under Ar condition.

The electrochemical reaction is correlated to physical characteristics of fuel surface. The physical characteristics were shown in Table II from BET method. The results show the surface area, total pore volume and mean pore diameter of each fuel. In the raw coal state, the Shenhua coal had the maximum surface area and pore volume of $6.1183 \mathrm{~m}^{2} / \mathrm{g}$ and $0.005088 \mathrm{~cm}^{3} / \mathrm{g}$, respectively. After volatilization process, the Openblue char had the highest surface area and pore volume due to much volatile matter. The mean diameter of each fuel was decreased, which indicates that the microporous was increased. Among the three coals, the Adaro coal showed the highest mean diameter of pores in raw state and char state. The gasification process changes not only the surface texture but also the surface functional group. XPS experiments were performed to analyze fuel component of the surface functional groups. The results were summarized in Table III. All samples had $\mathrm{C}, \mathrm{O}, \mathrm{Si}$ and $\mathrm{Al}$ in common. In the case of coals, the Openblue coal showed the most $\mathrm{C}$ content and Shenhua coal had the least $\mathrm{C}$ content on fuel surface. The $\mathrm{O}$ content of the fuel surface was an opposite to the $\mathrm{C}$ content. In the char state, the $\mathrm{O} / \mathrm{C}$ rate of the Adaro char was the highest surface oxygen content $25.26 \%$, while the Openblue char 
shows the lowest value $11.3 \%$. The ratio of total oxygen to carbon $(\mathrm{O} / \mathrm{C})$ indicates the degrees of surface functional groups. The highest $\mathrm{O} / \mathrm{C}$ ratio on the surface of the Adaro char may enhance the performance of DCFC system due to much surface functional groups.

TABLE II: BET RESULTS OF FUELS

\begin{tabular}{|c|c|c|c|c|}
\hline Fuels & \multicolumn{2}{|l|}{$\mathbf{S}_{\text {BET }}$} & $\mathbf{V}_{\text {total }}$ & $\mathbf{D}_{\text {pore }}$ \\
\hline Shenhua coal & \multicolumn{2}{|l|}{6.1183} & 0.005088 & 80.152 \\
\hline Adaro coal & \multicolumn{2}{|l|}{0.7968} & 0.002409 & 159.327 \\
\hline Openblue coal & \multicolumn{2}{|l|}{0.3227} & 0.001260 & 21.7568 \\
\hline Shenhua char & \multicolumn{2}{|l|}{162.9957} & 0.086632 & 3.7281 \\
\hline Adaro char & \multicolumn{2}{|l|}{212.2973} & 0.118518 & 4.2899 \\
\hline Openblue char & \multicolumn{2}{|c|}{280.4394} & 0.133381 & 2.7169 \\
\hline $\mathrm{D}_{\text {pore }}:$ mean di & \multicolumn{4}{|c|}{$\begin{array}{r}\mathrm{S}_{\mathrm{BET}} \text { : surface area of sample }\left(\mathrm{m}^{2} / \mathrm{g}\right) \\
\mathrm{V}_{\text {total }} \text { : pore volume of sample }\left(\mathrm{cm}^{3} / \mathrm{g}\right) \\
\text { of pores calculated by BJH adsorption test }(\mathrm{nm})\end{array}$} \\
\hline \multicolumn{5}{|c|}{ TABLE III: XPS RESULTS OF FUELS } \\
\hline Fuels & $\begin{array}{c}\text { C1s } \\
(\text { wt. \%) }\end{array}$ & $\begin{array}{c}\text { O1s } \\
(\text { wt. } \%)\end{array}$ & $\begin{array}{c}\text { Si2p+Al2p } \\
(w t . \%)\end{array}$ & $\begin{array}{l}\mathrm{O} / \mathrm{C} \\
(\%) \\
\end{array}$ \\
\hline Shenhua coal & 64.83 & 25.71 & 7.89 & 39.66 \\
\hline Adaro coal & 71.76 & 22.64 & 5.61 & 31.55 \\
\hline Openblue coal & 76.34 & 19.65 & 3.19 & 25.74 \\
\hline Shenhua char & 75.48 & 15.57 & 6.49 & 20.63 \\
\hline Adaro char & 71.9 & 18.16 & 9.12 & 25.26 \\
\hline Openblue char & 86.98 & 9.83 & 3.19 & 11.3 \\
\hline
\end{tabular}

\section{B. Characteristics of Electrochemical Oxidation Reaction}

Fig. 3 and Fig. 4 indicated the $i$-V curves and $i$-p curves of three coals and chars at same experimental conditions. The OCVs of each char were similar results (approximately -0.98 $\mathrm{V})$. The electrochemical reaction in the DCFC was usually divided into three polarizations; Activation polarization, Ohmic polarization, and Concentration polarization. The activation polarization is caused by energy level to activate fuel and electrolyte [11]. This is retarding factor that has an effect on all electrochemical reactions but is dominant at low current density. However, $i-\mathrm{V}$ curves of the Adaro char and Openblue char have different shapes. In the activation polarization region (from OCV to $-0.5 \mathrm{~V}$ ), the potential of raw coal state and Shenhua char tend to similarly decrease in activation region. In the case of the Adaro char and Openblue char, the curves drop almost linearly from OCV to $0.1 \mathrm{~V}$. This type of polarization behavior is more complex. The linear polarization is caused by the production of $\mathrm{CO}$ and $\mathrm{CO}_{2}$ gas bubbles from the coal particle [11]. These bubbles affect overall to lower mass transfer limitation and increase resistance. The potential of Openblue coal was sharply decreased and followed by Shenhua coal, and Adaro coal at the high current density region. The maximum power densities of Adaro char, Shenhua char, and Openblue char were showed 51.06, 35.02, and $31.46 \mathrm{~mW} / \mathrm{cm}^{2}$.

Fig. 4 shows the power density and potential of three raw coals according to current density at $700^{\circ} \mathrm{C}$. The OCVs of raw coals were similar to char state. The maximum power densities of Adaro coal, Shenhua coal, and Openblue coal were presented as $67.89,49.7$, and $51.13 \mathrm{~mW} / \mathrm{cm}^{2}$, respectively. In the case of Openblue coal which has the highest content of volatile gas, the maximum power density shows improvement of $20 \mathrm{~mW} / \mathrm{cm}^{2}$ in raw coal state. Through comparing results of raw coals and chars, the performance of carbonized coals was only affected by the fixed carbon and the specific area without influence of generated gases. From these results, it could be concluded that the gases produced in the pyrolysis process affected the overall performance.

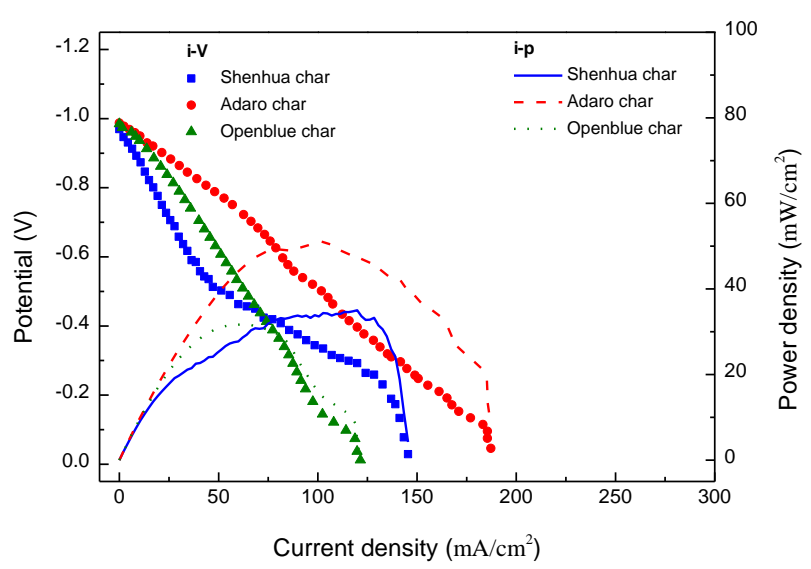

Fig. 3. $i$-V and $i$-p curve of three chars at $700^{\circ} \mathrm{C}$.

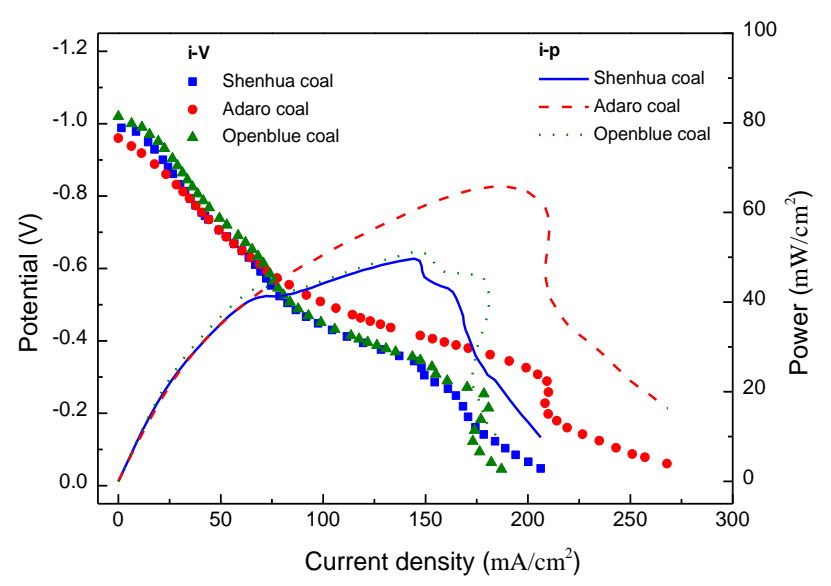

Fig. 4. $i$-V and $i$-p curve of three raw coals at $700{ }^{\circ} \mathrm{C}$.

\section{The Effect of Fuel Properties on Electrochemical Reaction}

Through the previous studies, the performance usually depends on surface area because of enlarged reactive region. Weaver et al. [12] suggested that the large surface area and poor crystallization have effects on the high performance. In contrast, Cooper et al. [13] reported that the reactivity doesn't depend on the surface area. In the char properties, the Openblue char shows the highest surface area, but the performance is the lowest. Because the surface area of Openblue char mainly consists of micropores. This means the micropores do not effect on performance because electrolyte can't pass through micropores. Therefore, it must be considered not only the surface area of fuel but also mean diameter of pores.

The specific surface area and pore volume of fuel samples had a connection with contacting possibility with electrolyte. In previous studies, the performance generally depends on surface area because of enlarged reactive region. From the BET results (Table II), the Openblue char is expected much higher performance than the Adaro char and Shenhua char. However, the maximum power density of Openblue char is the lowest value $\left(31 \mathrm{~mW} / \mathrm{cm}^{2}\right)$ shown in Fig. 4. 

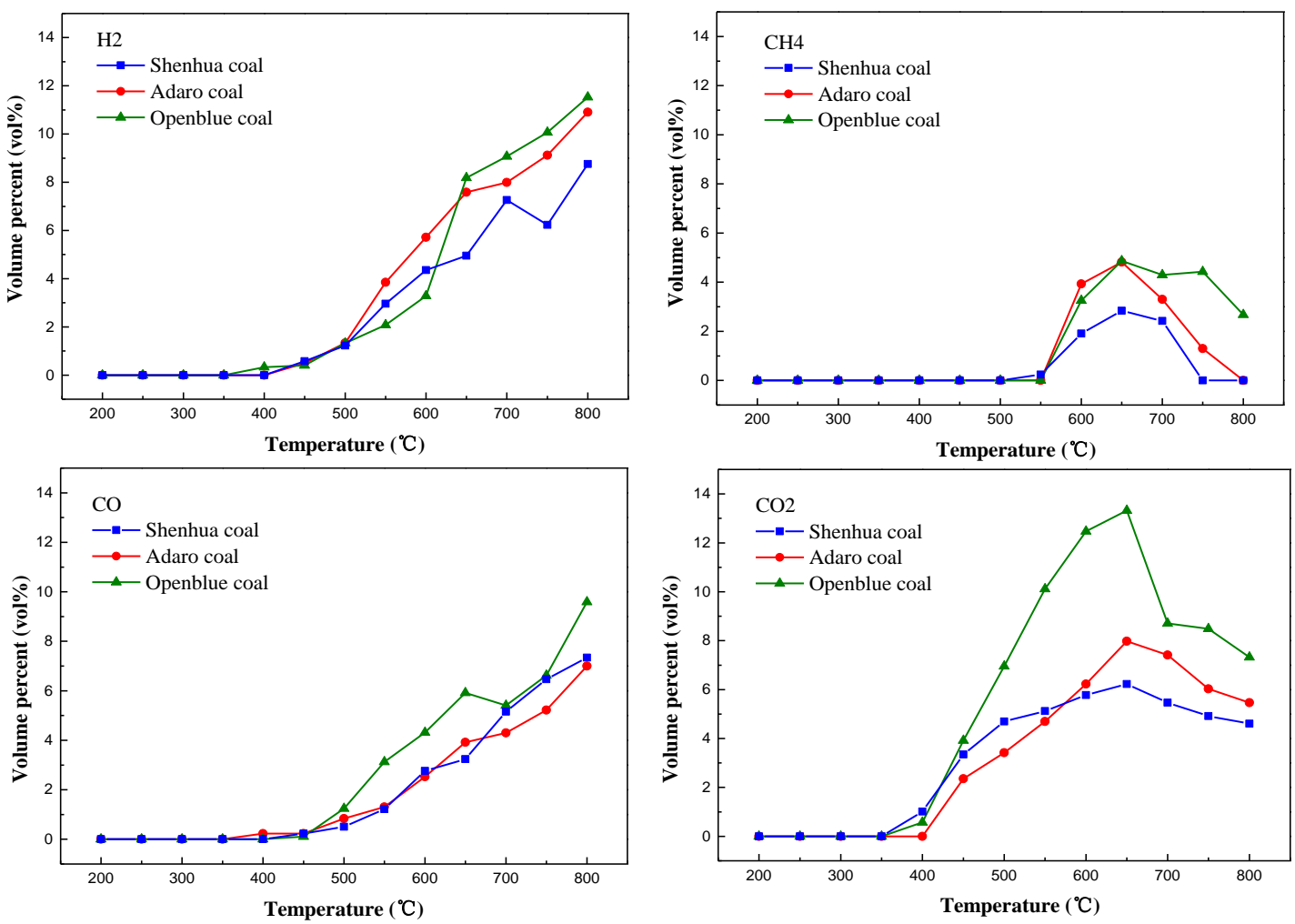

Fig. 5. Plot of $\mathrm{H}_{2}, \mathrm{CH}_{4}, \mathrm{CO}$, and $\mathrm{CO}_{2}$ volume percent of coals according to temperature until $800^{\circ} \mathrm{C}$.

The existence of a narrow pore size of fuels makes the entry of the electrolyte into the pores more difficult. The non-accessible pores do not contribute to the electrical double layer between carbon and electrolyte. Therefore, the Openblue coal has lower performance than expected. In other words, the performance of DCFC system depends on the pore size distribution as well as the specific surface area.

The ratio of total oxygen to carbon $(\mathrm{O} / \mathrm{C})$ indicates the degrees of surface oxidation of carbon and the surface functional groups including oxygen. The atomic concentrations of carbon and oxygen on the fuel surface obtained by XPS are shown in Table III. From the XPS results, the Adaro char has the highest surface oxygen content, while the Openblue char shows the lowest value. In spite of the insufficiency of the carbon concentration, the higher oxygen to carbon rate of Adaro char promote the electrochemical reactions [8]-[11]. Since Openblue char had low amount of oxygen, the potential cannot be maintained at the high current density which requires a lot of electron transfer. This result shows good agreement with the maximum power density of chars.

As shown by the study of surface chemical properties, The Adaro char had the highest surface functional groups and this means a large number of free reactive sites [3]. This is important to understand the enhanced anodic discharge rate in the DCFC tests. The high surface oxygen groups such as the carbonyl groups contribute to increase capacitance [14]. The additional formation of $\mathrm{CO}$ and $\mathrm{CO}_{2}$ from dissociation of surface functional groups could increase the performance of system. Using the coal as fuel of DCFC has higher performance than graphite particle which consist of $99 \%$ carbon due to facilitation the electrochemical oxidation of the solid carbon [15]. The more surface oxygen groups also enhance the wettability between the surface of carbonaceous fuels and electrolyte. Because of this reason, the resistance of DCFC system is decreased. Therefore, the Adaro chars present much higher performance than the other chars in the DCFC system. As discussed previously, the ratio of total oxygen to carbon that is surface functional groups containing oxygen is affected by the electrochemical reaction of char more than the surface area in DCFC [16], [17].

\section{Fuel Gasification}

Through the results of char and raw coal, the raw coal showed the higher performance due to volatile gases. The gases produced from fuels are important to predict performance because partial pressure has a direct influence on the potentials. T. Siengchum et al. investigated the performance of solid carbon, $\mathrm{H}_{2}, \mathrm{CO}$, and $\mathrm{CO}_{2}$ based on SOFC [18]. They reported that solid carbon fuels show the lowest performance in comparison with $\mathrm{H}_{2}, \mathrm{CO}$, and $\mathrm{CO}_{2}$. They also researched that the addition of the $\mathrm{CO}_{2}$ increased $\mathrm{CO}$ formation and maximum power, which indicated the coupling of Boudouard reaction and $\mathrm{CO}$ electrochemical oxidation.

The solid carbon is reacted with carbonate ion as following (1) and generated electron on the DCFC.

$$
\mathrm{C}+2 \mathrm{CO}_{3}{ }^{2-} \rightarrow 3 \mathrm{CO}_{2}+4 \mathrm{e}^{-}
$$

Furthermore, $\mathrm{CO}, \mathrm{H}_{2}$, and $\mathrm{CH}_{4}$ produced from fuel can also improve performance because these gases were used as fuel in other fuel cell in previous research as following (2-4). [18], [19].

$$
\begin{gathered}
\mathrm{H}_{2}+\mathrm{CO}_{3}^{2-} \rightarrow \mathrm{CO}_{2}+\mathrm{H}_{2} \mathrm{O}+2 \mathrm{e}^{-} \\
\mathrm{CO}+\mathrm{CO}_{3}^{2-} \rightarrow 2 \mathrm{CO}_{2}+2 \mathrm{e}^{-} \\
\mathrm{CH}_{4}+\mathrm{CO}_{2} \rightarrow 2 \mathrm{H}_{2}+2 \mathrm{CO}
\end{gathered}
$$


To describe gas compositions of Anode electrode, the three samples were analyzed with molten carbonate using a gas chromatography. The gasification equipment was used to conduct the atmospheric pressure in Ar condition to evaluate the gasification at same condition of Anode side. Fig. 5 showed the experimental data of $\mathrm{H}_{2}, \mathrm{CH}_{4}, \mathrm{CO}$, and $\mathrm{CO}_{2}$ from gasification of $5 \mathrm{~g}$ raw coals and $30 \mathrm{~g} \mathrm{Li}-\mathrm{K}$ carbonate mixture with increasing temperature.

In testing mixture of fuel and electrolyte, gases were not extracted from the fuels. Above $350{ }^{\circ} \mathrm{C}, \mathrm{CO}_{2}$ was produced and the other gases were extracted in the order of $\mathrm{H}_{2}, \mathrm{CO}$, and $\mathrm{CH}_{4}$ according to increasing temperature. All fuels generated the each gas at almost similar temperature and trend. $\mathrm{H}_{2}$ was generated over $400^{\circ} \mathrm{C}$ and continuously increased until $800{ }^{\circ} \mathrm{C}$ The small amount of $\mathrm{CH}_{4}$ was produced over $550{ }^{\circ} \mathrm{C}$ compare to other gases. Among the three coal, $\mathrm{CH}_{4}$ volume percent of Openblue increases to $5 \mathrm{vol} \%$ at $650{ }^{\circ} \mathrm{C}$ then decreases to $800{ }^{\circ} \mathrm{C}$ reaching almost 3 vol\%.

According to the test of gasification of coal and electrolyte, $\mathrm{CO}_{2}$ was produced from $350^{\circ} \mathrm{C}$ and increases until $650{ }^{\circ} \mathrm{C}$. Among the samples, $\mathrm{CO}_{2}$ of Openblue coal was the highest and increased to reach about 14 vol\%. After temperatures rising up to $650{ }^{\circ} \mathrm{C}, \mathrm{CO}_{2}$ formation rate of three fuels decreases. One possibility of this $\mathrm{CO}_{2}$ formation may be due to the Boudouard reaction which is the redox reaction of a chemical equilibrium of carbon monoxide and carbon dioxide according to temperature. Above $650{ }^{\circ} \mathrm{C}$, the $\mathrm{CO}$ concentration was increased, on the contrary, the $\mathrm{CO}_{2}$ concentration was decreased with temperature. These results corresponded with the reverse Boudouard reaction $\left(\mathrm{CO}_{2}+\mathrm{C}\right.$ $\rightarrow 2 \mathrm{CO}$ ) that $\mathrm{CO}_{2}$ is dominated the product of carbon oxidation at anode under $650^{\circ} \mathrm{C}$ and $\mathrm{CO}$ is the dominant product higher than $650^{\circ} \mathrm{C}$.

$\mathrm{CO}_{2}$ volume percent of all samples was steady from $700{ }^{\circ} \mathrm{C}$ in Fig. 5, the constant behavior could be described as the self-decomposition of electrolyte. As reaching to the melting temperature, carbonates melts and the self-decomposition reaction of carbonate ions takes place:

$$
\mathrm{CO}_{3}{ }^{2-} \rightarrow \mathrm{CO}_{2}+\mathrm{O}^{2-}
$$

These decomposition processes of carbonates electrolyte is categorized as products: one is generation of $\mathrm{CO}_{2}$ given by (5) The other case is characterized by the generation of $\mathrm{CO}$ through an intra-molecular redox process, as has been shown in the case of alkali or alkaline earth carbonates in the literature [20]. The carbonate decomposition which leads to the $\mathrm{CO}$ formation given by (6) is initiated by intermolecular electron transfer from a reducing agent to $\mathrm{CO}_{3}{ }^{2-}$.

$$
\mathrm{CO}_{3}{ }^{2-}+\mathrm{C} \rightarrow 2 \mathrm{CO}+\mathrm{O}^{2-}
$$

Another reason of the trend of $\mathrm{CO}$ and $\mathrm{CO}_{2}$ is because the carbon and electrolyte were generated carbon monoxide than carbon dioxide. The electrolyte of alkali metal carbonate was used as catalyst at coal gasification. The metal carbonates melt at a lower temperature and provide a gas-phase metal. Gas-phase metal which is a strong base reacts with $\mathrm{CO}_{2}$ to produce $\mathrm{CO}$ [21].

From the gasification results with molten carbonate in our DCFC system, the composition of CO gas is same level with to the amount of $\mathrm{CO}_{2}$ at operating temperature. Considering $\mathrm{CO}$ production, the alternative electrochemical mechanism was proposed at high temperature in molten carbonate [8].

$$
\mathrm{C}+\mathrm{CO}_{3}{ }^{2-} \rightarrow \mathrm{CO}+\mathrm{CO}_{2}+2 \mathrm{e}^{-}
$$

At the operating temperature, the amount of whole gases produced from Openblue coal has the highest volume percent compare to other coals. This is a good agreement with the highest improvement of performance of the Openblue coals. This result which is relationship between the amount of whole gases and DCFC performance indicated that operating the DCFC in three raw coals produced $\mathrm{H}_{2}, \mathrm{CH}_{4}, \mathrm{CO}$, and $\mathrm{CO}_{2}$, and these gases affect to the DCFC performance.

\section{CONCLUSION}

The three coals which have different content of fixed carbon and volatile matter were investigated for electrochemical reaction and the effect of fuels properties at $700{ }^{\circ} \mathrm{C}$. The relationship between electrochemical reactions and fuel properties was found that the volatile matter, specific surface area, pore volume, and oxygen functional groups on the surface were considered the effect on the performance of DCFC. The ratio of oxygen to carbon on fuel surface which means the surface functional groups containing oxygen influence the electrochemical reactions of solid fuel. The pore size distribution has a significant effect on electrochemical reaction more than the specific surface area.

The DCFC performance was affected by volatile gases. The effect of gases was investigated comparing the performance raw coal and its char. The OCV, maximum power density, and maximum current density were increased on account of existence of volatile gas. Among three coals, the Openblue coal showed the highest improvement of performance like $20 \mathrm{~mW} / \mathrm{cm}^{2}$ of maximum power density. Therefore, the released gases during gasification process such as $\mathrm{H}_{2}, \mathrm{CH}_{4}, \mathrm{CO}$, and $\mathrm{CO}_{2}$ had an effect on $\mathrm{OCV}$, maximum power density, and maximum current density of DCFC system. The trend of $\mathrm{CO}$ and $\mathrm{CO}_{2}$ of gasification results is because $\mathrm{CO}_{2}$ was consumed by the reverse Boudouard reaction $\left(\mathrm{CO}_{2}+\right.$ $\mathrm{C} \rightarrow 2 \mathrm{CO}$ ) and the carbon and carbonate ions were generated carbon monoxide than carbon dioxide over $600{ }^{\circ} \mathrm{C}$.

\section{ACKNOWLEDGMENT}

This work was supported by the National Research Foundation of Korea (NRF) grant funded by the Korea government (MEST) (No. 2011-0027954) and the Human Resources Development program(No. 20124010203230) of the Korea Institute of Energy Technology Evaluation and Planning(KETEP) grant funded by the Korea government Ministry of Knowledge Economy.

\section{REFERENCES}

[1] S. Giddey, S. P. S. Badwal, A. Kulkarni, and C. Munnings, "A comprehensive review of direct carbon fuel cell technology," Progress in Energy and Combustion Science, vol. 38, pp. 360-399, 2012.

[2] G. A. Hackett, J. W. Zondlo, and R. Svensson, "Evaluation of carbon materials for use in a direct carbon fuel cell," J. Power Sources, vol. 168, no. 1, pp. 111-118, 2007. 
[3] N. J. Cherepy, R. Krueqer, K. J. Fiet, A. F. jankowski, and J. F. Cooper, "Direct conversion of carbon fuels in a molten carbonate fuel cell," Journal of the Electrochemical Society, vol. 152, no. 1, pp. A80-A87, 2005.

[4] D. Cao, Y. Sun, and G. Wang, "Direct carbon fuel cell: fundamentals and recent developments," Journal of Power Sources, vol. 167, no. 2, pp. 250-257, 2007

[5] D. G. Vutetakis, D. R. Skidmore, and H. J. Byker, "Electrochemical oxidation of molten carbonate-coal slurries," Journal of the Electrochemical Society, vol. 134, no. 12, pp. 3027-3035, 1987.

[6] X. Li, Z. Zhu, R. D. Marco, J. Bradley, and A. Dicks, "Evaluation of raw coals as fuels for direct carbon fuel cells," Journal of Power Sources, vol. 195, no. 13, pp. 4051-4058, 2010.

[7] X. Li, Z. Zhu, R. D. Marco, A. Dicks, and J. Bradley, "Factors that determine the performance of carbon fuels in the direct carbon fuel cell," Industrial \& Engineering Chemistry Research, vol. 47, no. 23, pp. 9670-9677, 2008.

[8] X. Li, Z. Zhu, J. Chen, R. D. Marco, and A. Dicks, "Surface modification of carbon fuels for direct carbon fuel cells," Journal of Power Sources, vol. 186, no. 1, pp. 1-9, 2009.

[9] S. Y. Ahn, S. Y. Eom, Y. H. Rhie, Y. M. Sung, and C. E. Moon, "Utilization of wood biomass char in a direct carbon fuel cell (DCFC) system," Applied Energy, vol. 105, pp. 207-216, 2013.

[10] S. Y. Ahn, S. Y. Eom, Y. H. Rhie, Y. M. Sung, and C. E. Moon, "Application of refuse fuels in a direct carbon fuel cell system," Energy, vol. 51, no.1, pp. 447-456, 2013.

[11] A. Elleuch, A. Boussetta, and K. Halouani, "Analytical modeling of electrochemical mechanisms in $\mathrm{CO} 2$ and $\mathrm{CO} / \mathrm{CO} 2$ producing direct carbon fuel cell," J. Electroanal. Chem., vol. 668, pp. 99-106, 2012.

[12] R. D. Weaver, S. C. Leach, and L. Nanis, "Electrolyte management for the coal air fuel cell," in Proc. The 16th Intersociety Energy Conversion Engineering Conference, NY, USA, 1981, pp. 717-721.

[13] J. F. Cooper, "Reactions of the carbon anode in molten carbonate electrolyte," presented at Direct Carbon Fuel Cell Workshop, NETL, Pittsburg, PA, USA, 30th July, 2003. [Online]. Available: http://www.netl.doe.gov/publications/proceedings/03/dcfcw/Cooper\% 202.pdf.

[14] Y. B. Xie, W. M. Qiao, W. Y. Zhang, G. W. Sun, and L. C. Ling, "Effect of the surface chemistry of activated carbon on its electrochemical properties in electric double layer capacitors," New Carbon Materials, vol. 25, no. 4, pp. 248-254, 2010.

[15] S. Y. Ahn, "Effect of morphological property and chemical composition of solid fuels on the electrochemical reaction in the molten carbonate," Ph.D. dissertation, Dept. Mech. Eng., Pusan National Univ., Pusan, Korea, 2013.

[16] X. Li, Z. Zhu, R. D. Marco, J. Bradley, and A. Dicks "Carbon nanofibers synthesized by catalytic decomposition of methane and their electrochemical performance in a direct carbon fuel cell," Energy \& Fuels, vol. 23, no. 7, pp. 3721-3731, 2009.

[17] X. Li, Z. Zhu, R. D. Marco, J. Bradley, and A. Dicks "Modification of coal as a fuel for the direct carbon fuel cell," The Journal of Physical Chemistry, vol. 114, no. 11, pp. 3855-3862, 2009.

[18] T. Siengchum, F. Guzman, and S. S. C Chuang, "Analysis of gas products from direct utilization of carbon in a solid oxide fuel cell," Journal of Power Sources, vol. 213, pp. 375-381, 2012.

[19] E. P. Murray, T. Tsai, and S. A. Barnett, "A direct-methane fuel cell with a ceria-based anode," Nature, vol. 400, no. 6745, pp. 649-651, 1999.

[20] K. Nagase, T. Shimodaira, M. Itoh, and Y. Zheng "Kinetics and mechanisms of the reverse Boudouard reaction over metal carbonates in connection with the reactions of solid carbon with the metal carbonates," Phys Chem Chem Phys, vol. 1, pp 5659-5664, 1999.

[21] J. Nerlov, S. V. Christensen, S. Weichel, E. H. Pedersen, and P. J. Moller, "A photoemission study of the coadsorption of $\mathrm{CO} 2$ and $\mathrm{Na}$ on $\mathrm{TiO} 2(110)-(1 \times 1)$ and $-(1 \times 2)$ surfaces: adsorption geometry and reactivity," Surface Science, vol. 371, no. 2, pp 321-336, 1997.

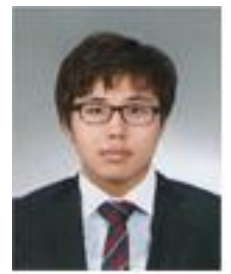

Seongyong Eom was born at Busan, Korea on 12 September 1989 and earned BSc in mechanical engineering from Pusan National University, Busan, Korea in 2012.

$\mathrm{He}$ is now enrolled a combined master's and doctorate program in Graduation School of Mechanical Engineering, Pusan National University, Busan, Korea. He is researching on direct carbon fuel cell.

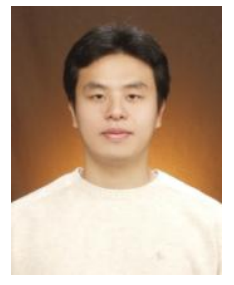

Seongyool Ahn was born at Busan, Korea on 5 April 1979. He is an expert on coal reaction chemistry and got the Ph.D degree from Pusan National University in 2013.

$\mathrm{He}$ is particularly interested in numerical calculation of coal combustion and now working at CRIEPI in Japan

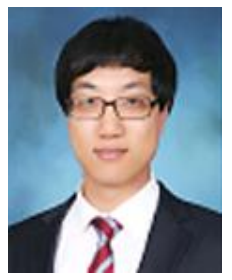

Younghoon Rhie was born at Seoul, Korea on 26 Febuary 1987 and earned BSc in mechanical engineering from Pusan National University, Busan, Korea in 2012

$\mathrm{He}$ is now enrolled a master's program in Graduation School of Mechanical Engineering, Pusan National University, Busan, Korea. He is researching on direct carbon fuel cell.

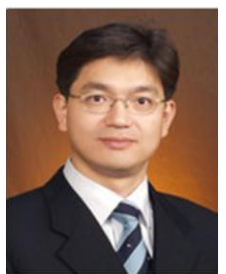

Gyungmin Choi earned Ph.D. in mechanical engineering from Pusan National University, Busan, Korea in 1997 and from Osaka University, Osaka, Japan in 2002.

$\mathrm{He}$ is a professor in School of Mechanical Engineering, Pusan National University, Busan, Korea.

Prof. Choi is in charge of general affairs for the Korean Society of Combustion.

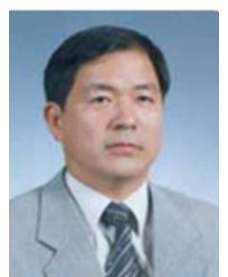

Duck Jool Kim earned Ph.D. in mechanical engineering from Kyungpook National University, Daegu, Korea

$\mathrm{He}$ is a professor in School of Mechanical Engineering, Pusan National University, Busan, Korea Prof. Kim was in charge of a vice-president for the Institute for Liquid Atomization and Spray Systems-Korea. 